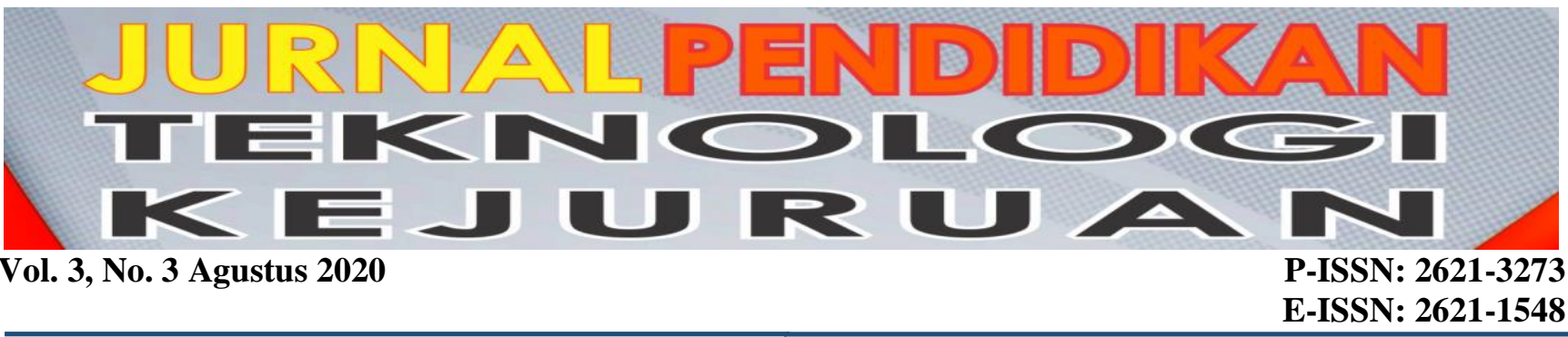

\title{
DEVELOPMENT OF INTERACTIVE LEARNING MEDIA OF AUTOMOTIVE LIGHTER VEHICLE MAINTENANCE MACHINE IN SMK N 1 PADANG
}

\author{
Meiyaldi Eka Putra ${ }^{1}$ dan Hasan Maksum ${ }^{2}$ \\ 1.2 Technology and Vocational Education, Faculty of Engineering, Universitas Negeri Padang. \\ "Corresponding author, e-mail: meiyaldi.my@gmail.com*
}

\begin{abstract}
Abstrak - Learning Media for Automotive Vehicle Engine Maintenance still uses a simple medium consisting of whiteboards and worksheets, which encourages less effective learning to develop more interactive media and supports students to more easily understand the basic concepts of Automotive Light Vehicle Engine Maintenance lessons. This development research aims to develop interactive learning media that is packaged interactively in the subject of Automotive Light Vehicle Engine Maintenance. This research method is R\&D with One Group PretestPosttest design. The procedure of this research was carried out in the stages of defining, designing and developing. The subjects of this study were 24 students from SMK N 1 Padang in class XI OTO A. The data collected in this study consisted of primary data obtained directly from respondents in the format obtained. This research instrument consisted of a questionnaire of validity, practicality and effectiveness. The research data collected was analyzed using $t$ test analysis. The results obtained from this research and development are as follows: (1) the validity of interactive learning media is stated to be very valid from didactic, construction and technical requirements with an average score of $94.16 \%$. (2) The practicality of interactive learning media is stated to be very practical based on teacher responses with an average score of $95 \%$, based on student responses also expressed very practical with an average score of $91.17 \%$. (3) The effectiveness of interactive learning media can be seen from student learning outcomes before and after using the media. This is evidenced by the significant differences in the use of interactive learning media obtained from student learning outcomes. Improved student learning outcomes are changed by the students' completeness value of KKM with an average value of 86.61 , which means students are complete in learning.
\end{abstract}

Keywords: Interactive Learning Media, Automotive Light Vehicle Engine Maintenance, Learning Outcomes

Copyright @ 2020 JPTK. All rights reserved

\section{INTRODUCTION}

Teachers are seen as agents of modernization in all fields through educational programs for their students. In making efforts to achieve educational goals in schools, teachers must use methods and methods that attract students so that the learning process will be fun and provide optimal learning outcomes. The strategy used by the teacher in the teaching and learning process is an important and supportive factor in achieving educational goals in schools.

The importance of the learning process to improve the quality of human resources, educational institutions SMK N 1 Padang has endeavored through various efforts so that education is higher quality. Among the efforts undertaken are implementing learning in accordance with process standards and assessment standards.
Maintenance of Automotive Light Vehicle Machines is also a subject in Automotive which is very important to be mastered by students in order to improve students' skills and competencies in the field of Automotive itself. Where students are expected to graduate later to be able to have skills that can be for them to earn income and work in the field in industry. So the rapid competition that occurs in the industry makes students must be really ready to face all obstacles that will occur, one of which must have the competence to understand about machine maintenance in Automotive. Expected level of competence in learning Light Vehicle Automotive Engine Maintenance Vocational Automotive students are students can reach the level that has the skills and ability to understand, understand, repair, arrange, analyze all the damage from Automotive Light 
Vehicle Engine Maintenance as they are prepared to be able to plunge directly into the world of work.

But in reality the learning outcomes of Automotive Light Vehicle Engine Maintenance subjects at SMK N 1 Padang, especially in class XI OTO A, the automotive majors are still relatively low, so efforts should be made to improve them. Low learning outcomes are problems that are worth solving.

The low student learning outcomes cannot be separated from the lack of motivation and interest of students in participating in learning so that ultimately affects student learning outcomes. In addition, the inadequate learning media used by teachers in teaching and learning can also affect the lack of student activity in the classroom, and if students are less active in the learning process activities it is likely that students will get low learning outcomes.

The author still feels the lack of learning software material for Automotive Light Vehicle Engine Maintenance which is packaged in an interactive form, so that students can learn more independently and actively. Departing from this Adobe Flash Program or formerly called Macromedia Flash can certainly be the first offer to provide solutions to the problems above. The Adobe Flash program is a combination of concept features that can be utilized in education. Multimediabased learning can certainly be used in education. Multimedia-based learning can certainly provide more interesting subject matter, not monotonous, and facilitate delivery. Students can learn certain subject matter independently with a computer equipped with multimedia programs. We can say that multimedia technology has advantages such as being more attractive, effective and students can be active.

Interactive media is one of the learning media that can display moving images accompanied by sound. The advantage of interactive media is to increase students' interest and interest in understanding the lessons to be given, looking at the form of components that exist in the large components of an object and knowing also its function. Interactive media is a media that presents an image of the shape of an object that will be introduced, how the workings of that object can move and run something is very well suited to learning automotive practice which consists of several moving components.

Researchers consider it important to develop learning media subjects for Maintenance of Automotive Light Vehicle Machines at SMK N 1 Padang TP. 2020/2021, because it can improve student learning outcomes. Development of interactive learning media on the subject of Automotive Light Vehicle Engine Maintenance to produce learning media that are valid, practical and effective.

\section{METHOD}

\section{A. Development Model}

The development research model used is the 4-D (Four D) model development model with stages, namely: define, design, develop, and disseminate (Trianto, 2007, p. 189) This Four D model has advantages including: a) more appropriate to be used as a basis for developing learning tools instead of learning systems, b) the description looks more complete and systematic, c) in its development it involves expert judgment so that before field testing the learning tools have been revised based on evaluation and expert advice. (A. Wawan and Dewi, 2010: 25).

\section{B. Development Procedure}

The steps for developing learning media for Light Vehicle Engine Maintenance lessons can be seen in Figure 1:

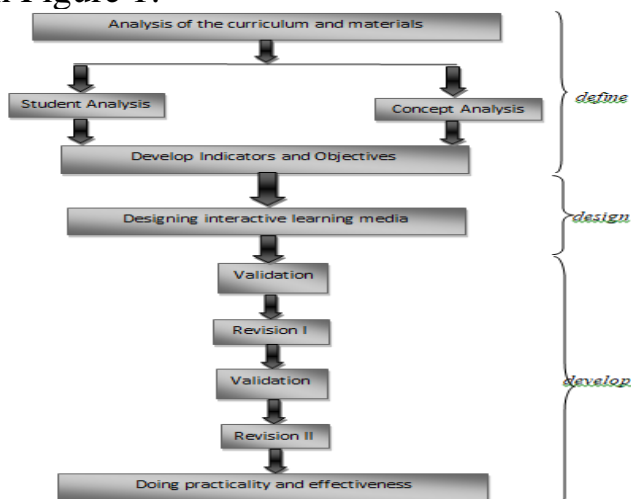

Figure 1: Learning Media Research Procedure Source: Modified from (Trianto, 2007)

\section{Trial Subjects}

The test subjects were 24 students of the Automotive Study Program at SMKN 1 Padang class XI OTO A in the 2020/2021 academic year.

\section{Types of Data}

This type of research data is primary data, namely data obtained directly from the validator, teacher and students which are taken through a questionnaire that tests the validity, practicality and effectiveness of the interactive learning media developed.

Sources of data in the study:

1. Media validation data is obtained from instruments filled in by content and construction experts / experts consisting of 4 people, consisting of 2 teachers teaching the Automotive Study Program at SMK Negeri 1 Padang and 2 lecturers from FT UNP.

2. Data on the practicality of the media were obtained from the usability data of video media. Data on the use of video media, obtained data on student and teacher responses. 
3. Data on media effectiveness is obtained from student learning activities and student cognitive learning outcomes after learning using interactive learning media.

\section{Instruments for collecting data}

This research instrument was used to collect data. The instruments used in this study were as follows:

\section{Validation sheet}

This validation sheet is a sheet made by the researcher and given to the validator to validate. There are three media criteria that are said to be valid if they meet the following criteria:

\section{a) Didactic requirements}

This is related to the process of finding concepts according to the applicable curriculum, paying attention to individual differences so that good media can be used to measure students' abilities.

\section{b) Construction requirements}

This is related to sentence structure, simplicity of word use and clarity which is basically effective and understood by students.

\section{c) Technical requirements}

Concerned with the use of language, writing, pictures and appearance in making learning media.

2. Questionnaire practicality test of interactive learning media

Questionnaire for practicality of interactive learning media by teachers and students on interactive media is used to get practical data by teachers and students on the ease and practicality of interactive learning media being developed. The teacher practicality questionnaire is an assessment in the form of a score filled in by the teacher about the practicality and convenience after using interactive learning media in the light vehicle engine maintenance lesson. The questionnaire for the practicality of the media by the teacher includes: ease of use of media, time used, easy to interpret, has the same equivalence and generates interest.

\section{Data analysis technique}

The data obtained in this study were analyzed to determine the feasibility of the learning tools being developed. Data analysis was carried out in the following ways:

\section{Media validation analysis}

Analysis of the results of media validation uses the following steps:

a) Give the answer score with the following criteria:

$4=$ very valid, $3=$ valid, $2=$ invalid, $1=$ very invalid.

b) Add scores for each validator for all indicators.

c) Validation is given by the formula:
Validity value $=\frac{\text { Score obtained }}{\text { Maximum score }} \times 100 \%$

\section{Analysis of media practicality data}

Practicality analysis is carried out by providing an assessment of each item. The scores given are: $4=$ very practical, $3=$ practical, $2=$ impractical, $1=$ very impractical.

Practicality score $\frac{\text { Sum of all scores }}{\text { Sum of maximum scores }} \times 100 \%$

\section{Analysis of media effectiveness data}

a) Analysis of student activity observation data

Student learning activity data is processed using a quantitative approach in the form of a percentage formula (\%) which is stated by Sudijono (2009: 43):

$$
\mathrm{P}=\frac{F}{N} \times 100 \%
$$

$\mathrm{P}=$ percentage of students who are actively involved

$\mathrm{F}=$ frequency of each activity

$\mathrm{N}=$ total number of students

b) Design student learning tests with interactive learning media

The research design used was One Group Pretest-posttest. Due to the limitations of researchers, the study was only conducted for one class. In this design, before using interactive learning media, the trial subject is given a pretest (initial test) and the end of learning using video is given a posttest (final test).

Table 1. Learning outcomes test of the One Group Pretest-Posttest Design design

\begin{tabular}{|c|c|c|}
\hline Pretest & Treatment & Posttest \\
\hline $\mathrm{O}_{1}$ & $\mathrm{X}$ & $\mathrm{O}_{2}$ \\
\hline
\end{tabular}

Source: Sugiyono (2009)

Information:

O1: Pre-test before treatment is given

O2: Posttest after the treatment is given

$\mathrm{X}$ : Treatment of study groups using interactive learning media

\section{c) Student learning outcomes}

The cognitive aspect of learning outcomes is used to measure the increase in learning outcomes obtained from giving test questions to students before and after learning using interactive learning media.

Then the scores of student learning outcomes after using interactive learning media were analyzed to see the level of achievement of student 
learning outcomes in the subject of Maintenance of Light Vehicle Machines, by adding the value of student learning outcomes with the value of practice and assignments. The value of learning outcomes obtained by students is converted into the front value of the 0-100 range. Student learning outcomes are categorized as follows:

Table 2. Categories of Interactive Learning Media Effectiveness

\begin{tabular}{|c|c|c|}
\hline No & Achievement Rate (\%) & Category \\
\hline 1 & $81-100$ & Very good \\
\hline 2 & $61-80$ & Good \\
\hline 3 & $41-60$ & Enough \\
\hline 4 & $21-40$ & Less \\
\hline 5 & $0-20$ & Not good \\
\hline
\end{tabular}

Source: Arikunto (2006)

Standards applied to indicators of success in learning outcomes are KKM (Minimum Completeness Criteria), namely 80 .

\section{RESULTS}

\section{A. Test the validity of the Interactive Learning Media}

Validation of video media is validation of the resulting product design. In this case, before being tested, a validation stage is carried out for both content and media design.

After validation, interactive learning media can be used but a slight revision is made to interactive learning media based on suggestions from the validator, it can be seen in the table below:

Table 3. Product Revision Results

\begin{tabular}{|c|l|l|}
\hline No. & \multicolumn{1}{|c|}{$\begin{array}{l}\text { Media Before } \\
\text { Revision }\end{array}$} & Media After Revision \\
\hline 1. & $\begin{array}{l}\text { It is necessary to } \\
\text { consider the } \\
\text { composition of } \\
\text { cognitive, attitude } \\
\text { and psychomotor } \\
\text { use }\end{array}$ & $\begin{array}{l}\text { The use of media is } \\
\text { only in cognitive form } \\
\text { and for practice it is } \\
\text { only included how to } \\
\text { measure component } \\
\text { damage. }\end{array}$ \\
\hline 2. & $\begin{array}{l}\text { Use Arial, Tahoma } \\
\text { and Verdana letters }\end{array}$ & $\begin{array}{l}\text { Already using the } \\
\text { Tahoma letters }\end{array}$ \\
\hline 3. & $\begin{array}{l}\text { Pay attention to the } \\
\text { composition and } \\
\text { contrast of the } \\
\text { colors }\end{array}$ & $\begin{array}{l}\text { The color contrast } \\
\text { between the } \\
\text { background and the } \\
\text { text has been adjusted } \\
\text { using the color wheel }\end{array}$ \\
\hline
\end{tabular}

\begin{tabular}{|c|l|l|}
\hline 4. & $\begin{array}{l}\text { Images and writing } \\
\text { on images must be } \\
\text { balanced }\end{array}$ & $\begin{array}{l}\text { Balancing between } \\
\text { writing and images } \\
\text { in the media }\end{array}$ \\
\hline 5. & $\begin{array}{l}\text { Make evaluations } \\
\text { in an interactive } \\
\text { form }\end{array}$ & $\begin{array}{l}\text { The exercises and } \\
\text { questions have } \\
\text { been made in an } \\
\text { interactive form }\end{array}$ \\
\hline 6. & $\begin{array}{l}\text { The stem } \\
\text { (statement) of the } \\
\text { test is corrected } \\
\text { after the rules for } \\
\text { preparing the test }\end{array}$ & $\begin{array}{l}\text { Already changing } \\
\text { and paying } \\
\text { attention to the } \\
\text { rules for preparing } \\
\text { objective tests }\end{array}$ \\
\hline 7. & $\begin{array}{l}\text { The size of the } \\
\text { writing for the } \\
\text { media must be be } \\
\text { considered }\end{array}$ & $\begin{array}{l}\text { The size of the } \\
\text { media writing has } \\
\text { been changed } \\
\text { according to the } \\
\text { rules for making } \\
\text { slides }\end{array}$ \\
\hline
\end{tabular}

B. Practicality Test of Interactive Learning Media

At the end of the learning activity, teachers and students were asked to fill out a practicality questionnaire for the cooling system interactive learning media. The results of filling out practical instruments by the teacher can be seen in table 4 .

Table 4. Assessment of the Practicality of Interactive Learning Media by the Teacher

\begin{tabular}{|c|l|c|c|}
\hline No. & \multicolumn{1}{|c|}{ Indicator } & $\begin{array}{c}\text { Average } \\
(\%)\end{array}$ & Category \\
\hline 1. & $\begin{array}{l}\text { Ease of use of } \\
\text { media }\end{array}$ & 100 & $\begin{array}{c}\text { Very } \\
\text { Practical }\end{array}$ \\
\hline 2. & $\begin{array}{l}\text { Time spent in } \\
\text { implementation }\end{array}$ & 100 & $\begin{array}{c}\text { Very } \\
\text { Practical }\end{array}$ \\
\hline 3. & $\begin{array}{l}\text { Easy to interpret } \\
\text { Pas the same } \\
\text { equivalent }\end{array}$ & 87,5 & Practical \\
\hline 5. & Practical \\
\hline \multicolumn{2}{|c|}{ Average interest } & 100 & $\begin{array}{c}\text { Very } \\
\text { Practical } \\
\text { Very } \\
\text { Practical }\end{array}$ \\
\hline
\end{tabular}

The data from the results of filling out the questionnaire on the use of interactive learning media by students which were filled in after using interactive learning media in the cooling system subject both in small groups and the actual class assessment can be seen below: 
Table 5. Learning Media Usability Assessment by Students in Small Groups

\begin{tabular}{|c|c|c|c|}
\hline No. & Indicator & $\begin{array}{c}\text { Average } \\
(\%)\end{array}$ & Category \\
\hline 1. & Learning aspects & $86.43 \%$ & Practical \\
\hline 2. & $\begin{array}{c}\text { Standard aspects } \\
\text { of content }\end{array}$ & $85,75 \%$ & Practical \\
\hline 3. & $\begin{array}{l}\text { Aspects of the } \\
\text { media elements }\end{array}$ & $87,5 \%$ & Practical \\
\hline & Average & $86,56 \%$ & Practical \\
\hline
\end{tabular}

Interactive learning media products that are valid are used again for limited trials of all students who are taking the odd semester cooling system subject for the 2020/2021 academic year, totaling 24 students. For more details, see the following table:

Table 6. Interactive Learning Media Usability Assessment Cooling System Subject by Students

\begin{tabular}{|c|c|c|c|}
\hline No. & Indicator & $\begin{array}{c}\text { Average } \\
(\%)\end{array}$ & Category \\
\hline 1. & $\begin{array}{c}\text { Learning } \\
\text { aspects }\end{array}$ & $94,01 \%$ & $\begin{array}{c}\text { Very } \\
\text { practical }\end{array}$ \\
\hline 2. & $\begin{array}{c}\text { Standard aspects } \\
\text { of content }\end{array}$ & $89,91 \%$ & Practical \\
\hline 3. & $\begin{array}{c}\text { Aspects of the } \\
\text { media elements }\end{array}$ & $89,58 \%$ & Practical \\
\hline & Average & $91,17 \%$ & $\begin{array}{c}\text { Very } \\
\text { practical }\end{array}$ \\
\hline
\end{tabular}

\section{Test the Effectiveness of Interactive Learning Media}

\section{1)Data on student learning activities}

Data on student learning activities in learning were obtained from the results of observations filled in by observers who consisted of two observers, both of whom were teachers of the automotive engineering study program who taught at SMK Negeri 1 Padang. Activity data is obtained during learning activities using interactive learning media.

\section{2) Data on student learning outcomes}

Student learning outcomes data aims to see the extent of student learning success in learning using interactive learning media. The learning outcome data were obtained from the cognitive aspects of learning outcomes only. The results of the note scores were $30 \%$, the test scores were $40 \%$ and the assignments were $30 \%$.

To test the significance of the difference, the $t$ test analysis was carried out, the results of the $t$ test analysis showed $t$ count $>t$ table $(7.65>2.77)$, then $\mathrm{H} 0$ was rejected and $\mathrm{Ha}$ was accepted. So, there are significant differences from before and after the use of interactive multimedia learning media.

\section{DISCUSSION}

The development of interactive learning media is designed according to the needs and problems in research, at this stage the researcher compiles a program that includes all interactive components, namely taking videos or animations about how the cooling system works on YouTube. Then, make the video smaller, from $\mathrm{MB}$ to $\mathrm{KB}$ in size and incorporate all the video and animation worth watching as well as the shape of the components of the cooling system. Screen design using Microsoft Office PowerPoint. All materials are inserted into the PowerPoint media, in order to record the slides that have been made.

Based on the validity test of interactive learning media, an average score of $94.16 \%$ was obtained with a very valid category from the validator. According to Arikunto's opinion (2006: 63) that validation is a measure that shows the level of reliability or validity of a measuring instrument. Distribution of validation sheets to five validators consisting of education experts with 20 assessed aspects of the assessment. Thus, it can be said that interactive multimedia learning media can improve students' abilities in learning.

The data above is also equipped with practicality tests that have been carried out to see the practicality of interactive learning media on the subject of light vehicle engine maintenance, with predefined indicators. So, for the practicality given by the teacher through filling out the questionnaire, the result was that the average score for all aspects of the assessment of the two teachers obtained a calculation of $95 \%$ with a very practical category. Meanwhile, the practicality analysis based on student assessment through a questionnaire showed that the average percentage score for all aspects of the assessment of all students was at a percentage score of $91.17 \%$ with the very practical category.

The results of the data test of the effectiveness of interactive learning media are known through the assessment of improving student learning outcomes before and after using the interactive multimedia learning media. Then the average score of student learning outcomes after using the media was analyzed to see the level of achievement of learning outcomes in the cooling system subject, by adding these values.

The assessment of the known student learning outcomes was analyzed by test analysis. The result of $\mathrm{t}$ test analysis shows $\mathrm{t}$ count $>\mathrm{t}$ table (7.65> 2.77), then $\mathrm{HO}$ is rejected and $\mathrm{Ha}$ is accepted. So, there are significant differences from before and after the use of interactive multimedia learning media 


\section{CONCLUSION}

Based on the results of research and discussion, the following conclusions can be drawn:

1. Interactive learning media has been produced with products in the form of interactive learning media on light vehicle engine maintenance subjects, especially the competency standards for identifying cooling systems with the stages of define, design and develop.

2. The developed interactive learning media is said to be valid after being validated by 4 validators. The results of the assessment with an average percentage score of $94.16 \%$ with a very valid category.

3. The interactive learning media developed can be said to be practical after being tested on two teachers. The results of the assessment with an average score of $95 \%$ in the very practical category. Then, it was tested on students with an average percentage score of $91.17 \%$ with a very practical category.

4. Interactive learning media developed can be said to be effective after it is known by testing the effectiveness of students' scores during the learning process. There was an average score before using the media that was 62 and after using the media the average score increased to 86 . The assessment of the known student learning outcomes was analyzed by $t$ test analysis. The result of $t$ test analysis shows $t$ count $>t$ table $(7.65>2.77)$, then $\mathrm{H} 0$ is rejected and $\mathrm{Ha}$ is accepted.

\section{REFERENCES}

Arikunto, Suharsimi (2006). Prosedur Penelitian: Suatu Pendekatan Praktek. Jakarta: PT Rineka Cipta.

A. Wawan dan Dewi, 2010, Teori dan Pengukuran Pengetahuan, Sikap dan Perilaku Manusia, Yogyakarta: Nuha Medika.

Dwi Yuniawati, Liana, \& Syariffuddien Zuhrie, Muhamad (2019). Pengembangan Media Pembelajaran Multimedia Interaktif Mata Pelajaran Penerapan Sistem Radio dan Televisi Di SMK Negeri 3 Surabaya. Jurnal Pendidikan Teknik Elektro, 8(2).

Hartono, H., Lesmana, C., Permana, R., \& Matsun, M. (2018). Pelatihan dan pendampingan pembuatan media pembelajaran berbasis multimedia interaktif. Transformasi: Jurnal Pengabdian Masyarakat, 14(2), 139-147.
Matsuri, J. D. Pengembangan Media Pembelajaran Tembang Macapat Berbasis Video Interaktif. Jurnal Pendidikan Dasar Universitas Sebelas Maret, 3(2), 119040.

Sudijono, Anas. 2009. Pengantar Statistik Pendidikan. Jakarta: Rajawali Press.

Suyitno, R. (2017). Pengembangan Media Pembelajaran Interaktif Macromedia Flash Kompetensi Pemeliharaan Sistem Tanda Dan Penerangan Kendaraan Ringan Di Smk Negeri 1 Sapuran. Auto Tech: Jurnal Pendidikan Teknik Otomotif Universitas Muhammadiyah Purworejo, 10(01).

Trianto, Model Pembelajaran Inovatif yang Berorientasi Konstruktivistik. Jakarta: Prestasi Sastra, 2007.

\section{Author's Biography}

Meiyaldi Eka Putra was born in Padang, May 4, 1994. The author is a graduate student in Technology and Vocational Education at Padang State University. The author completed a Bachelor's degree in the Automotive Engineering Education Program at Padang State University in 2017. 